\title{
Fungal Remains from the Subathu Formation of Dogadda, Uttarakhand, India
}

\author{
Rashmi Panwar*, O. P. Thakur, N. N. Dogra \\ Department of Kurukshetra University, Kurukshetra, Haryana, India \\ Email: ^rishabh_payal123@yahoo.com
}

How to cite this paper: Panwar, R., Thakur, O.P. and Dogra, N.N. (2020) Fungal Remains from the Subathu Formation of Dogadda, Uttarakhand, India. Open Journal of Geology, 10, 1198-1209. https://doi.org/10.4236/ojg.2020.1012059

Received: October 9, 2020

Accepted: December 20, 2020

Published: December 23, 2020

Copyright (c) 2020 by author(s) and Scientific Research Publishing Inc. This work is licensed under the Creative Commons Attribution International License (CC BY 4.0).

http://creativecommons.org/licenses/by/4.0/ (c) (i) Open Access

\begin{abstract}
The present paper deals with the new record of fungal remains from the Subathu Formation exposed along Dogadda-Kotdwar road section in Dogadda, Uttarakhand. The assemblage is composed of 13 species assignable to 10 genera. The important genera are Callimothallus senii, Haplopeltis mucoris, Haplopeltis sp., Parmathyrites sp., Phragmothyrites eocaenicus, Plochmopeltinites sp., Spinosporonites saxenae, Spinosporonites angularis and Trichothyrites padappakkarensis. The presence of microthyriaceous fungi in dominance suggests that the region experienced a warm and humid climate during the course of sediment deposition with thick vegetation providing suitable substrates for the growth and proliferation of fungi. Their presence depicts the prevalence of moist tropical type of vegetation during deposition in the area. The present fungal assemblage is assigned Late Palaeocene-Middle Eocene age.
\end{abstract}

\section{Keywords}

Fungal Remains, Subathu Formation, Palaeoclimate, Dogadda

\section{Introduction}

Nowadays, fungal remains studies along with spores/pollen provide significant records for palaeoenvironmental interpretations. Their diversity and frequency pattern help in deciphering the sequential history of changes which occurred in palaeoclimate and palaeo habitat of the area.

The term "Subathu" was initially coined by Medlicott in 1864. It represents the oldest sequence of the Palaeogene succession of Himalayan Foreland Basin succession. It has wide geographic distribution and attains its maximum thickness in N-W direction while pinches out in S-E direction. In Northwestern Himalaya, its thickness varies from about $400 \mathrm{~m}$ in Himachal Pradesh to about 175 
$\mathrm{m}$ in Jammu and Kashmir and about $60 \mathrm{~m}$ in Uttarakhand. This succession marks the beginning of the flexural depression of Himalayan Foreland basin resulted from the collision of Indian-Eurasian plates and subsequent closure of Tethys.

Although geological studies on the Subathu lithounit in Garhwal Syncline have been chiefly done by [1]-[8]. [4] studied in detail the Subathu Formation exposed in the Singtali, Nilkanth, Dhamand, Bidasini, and Dogadda area and recognised five major zones (Zone A-Zone E) in stratigraphic order and assigned Upper Paleocene to Early Eocene age to them. [5] gave detailed lithostratigraphy of Subathu Group exposed in Morni, Garkhal, Subathu, Kulra, Arki, Nilkanth and Dogadda blocks. Also considerable micropalaeontological work has been done on the Subathu sediments from the various regions of Uttarakhand by various workers. [9] recorded Nummulites cf. mamilla, Operculina patalensis, N. atacicus, Assilna granulosa chhumbiensis, Globorotalia sp. from the Subathu Formation of Dogadda, Garhwal Himalaya and assigned an Upper Paleocene to Lower Eocene age. [10] recorded lamellibranch genera Perna, Cardiocardita, Astarte from the Dogadda Formation in Garhwal Synform at Golikhet, Garhwal, U.P. On the basis of fossil records, the Subathu formation is considered to range in age from Upper Palaeocene to middle Eocene and the deposition of the lithounit in marine conditions.

Although, these workers deal with the foraminiferas and vertebrates, the fungal spores and their fruiting bodies seem to have been received no attention. Therefore, the present study is focused on the fungal remains from the Subathu sediments of the Dogadda area located in the Uttarakhand (Figure 1) because of its relevance in palaeoenvironmental considerations.

\section{Geological Setting}

Tectonically, Subathu Formation has thrusted contact with the crystalline rocks of Bijni tectonic unit to the northwest [11] and to the south, it is delimited by Krol Thrust. Lithologically, the entire Subathu succession of the area is comprised of splintery carbonaceous shale, ooidal ironstone, grey, red and green shales, limestone and sandstone. The litholog of the study area is given in (Figure 2).

The basal part of Subathu Formation is comprised of dark grey, non-calcareous \& poorly consolidated carbonaceous shale with coaly bands \& ooidal iron stone. The berthierine rich ooidal iron stone has sharp lower contact with sediments of Kakara Formation. The ooidal iron stone is overlain by the grey shale, siltstone with minor bands of green \& red shales with packstone containing foraminiferas. The top most part of the section is comprised of thick sandstone. The tectonic succession of the present study area is given in (Table 1).

\section{Material and Methods}

The present investigation has been carried out on 17 representative samples 

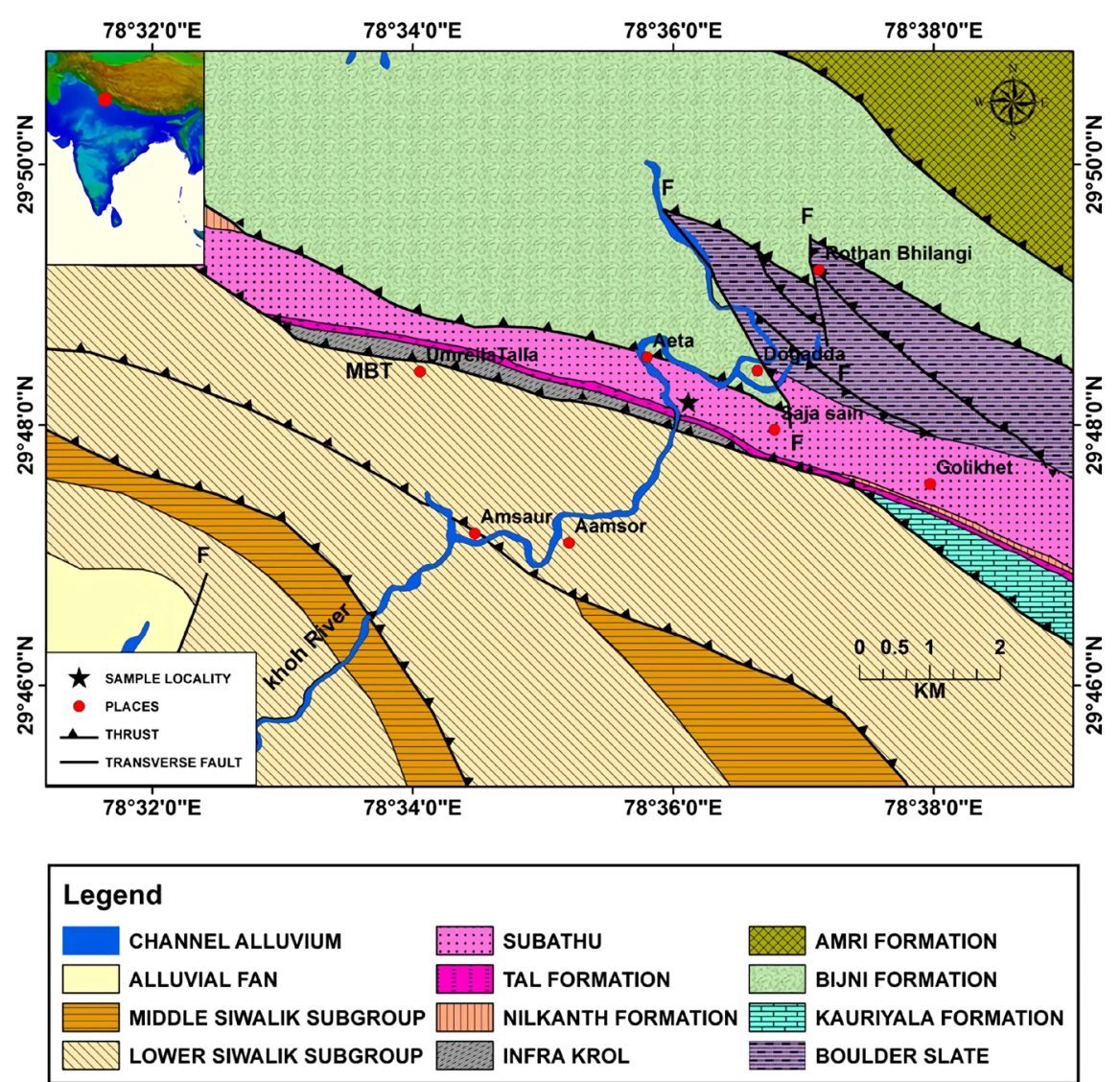

Figure 1. Geological map of Dogadda area, District Pauri Garhwal, Uttarakhand showing sampled locality.

Table 1. The Tectonic succession in the study area, Dogadda, Garhwal Himalaya.

\begin{tabular}{ccc}
\hline FORMATION & LITHOLOGY & AGE \\
\hline Amri & Schistose phyllites with granite & $\begin{array}{c}\text { Lower Palaeozoic } \\
\text { to Precambrian? }\end{array}$ \\
Lower Bijni & Quartzites, boulder slate, & Permian to Late \\
& gritty quartzites and sandy limestones & Carboniferous
\end{tabular}

Garhwal Thrust

Subathu

Tal

Krol
Intercalated bands of grey, green and purple shales, grey sandstones, and lenses of limestones and brownish shell marls

Early Eocene to

Upper Palaeocene

Early Palaeocene

to Cretaceous

Cretaceous? Jurrasic to Early

Paleozoic

Krol Thrust 


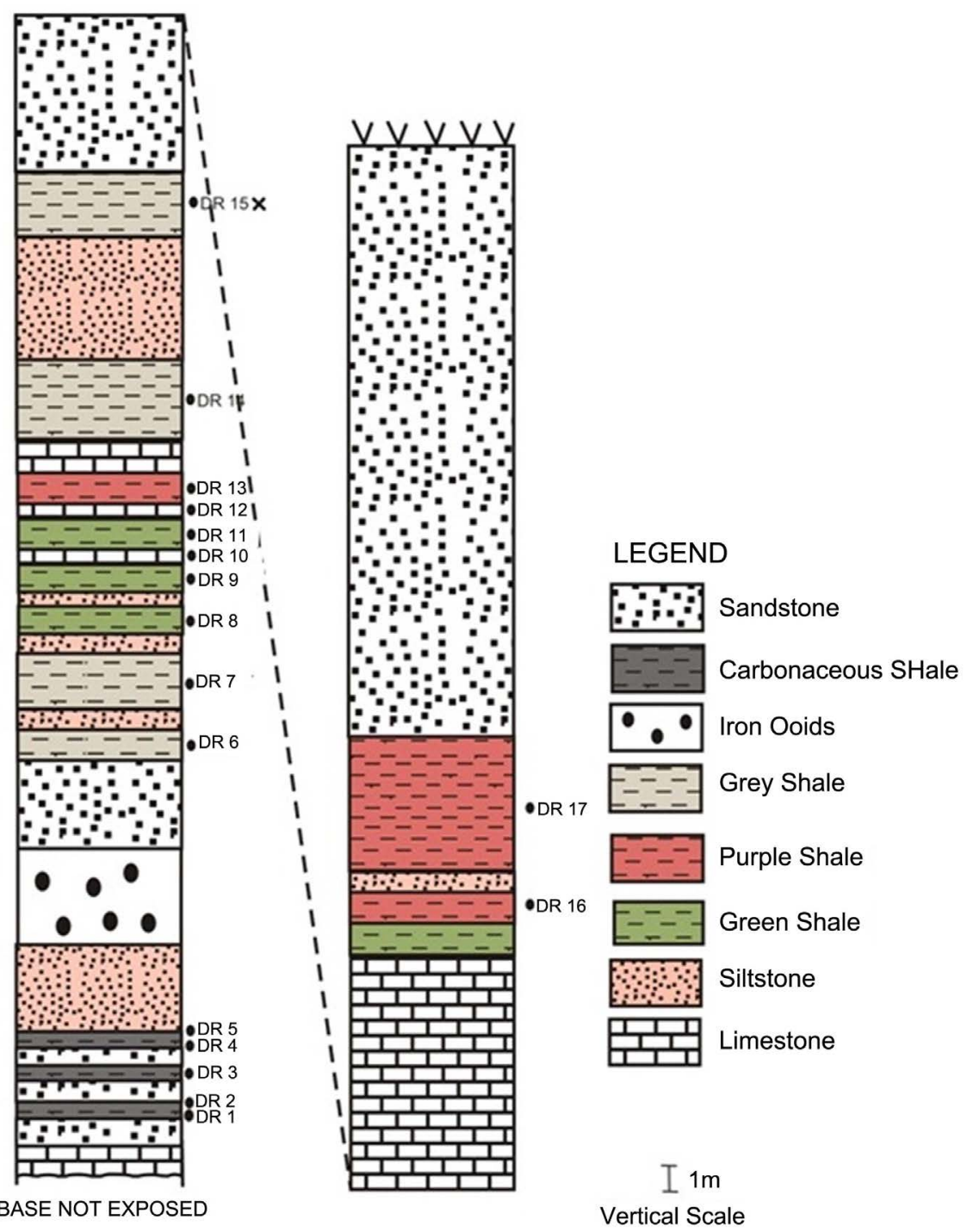

Figure 2. Litholog of the study area.

collected from $64 \mathrm{~m}$ thick lithosection of Subathu Formation of present area for processing using the standard maceration technique. For this qualitative approach, each sample was taken and crushed into pea size with the help of mortar and pestle. 10 - $15 \mathrm{gm}$ of each sample was taken and treated with $\mathrm{HCl}(40 \%)$ followed by HF (40\%) in order to remove carbonates and silicates, respectively. The residue left was sieved using 40 mesh size sieve to eliminate the remaining clay particles. Now the residue was treated with conc. $\mathrm{HNO}_{3}$ in order to oxidize the humic material. After digestion process, permanent slides were made using polyvinyl alcohol and Canada Balsam for palynomorph identification. Prepared slides were examined in transmitted light using Olympus light microscope and photographed.

\section{Results}

The fungal remains recovered from the Subathu Formation exposed along 
Dogadda-Kotdwar road section in Dogadda, Uttarakhand comprised of 13 species belonging to 10 form genera. Of these, 7 genera and 9 species of fungal fruiting bodies belong to mycrothyriaceaea, one diporicellaesporites species to phragmosporae, cleistothecium type, one inapertisporites species to amerosporae and fungal spore type-I have been recovered. The check list of the fungal remains is given in (Table 2).

The lithology of the Subathu Formation is shown in field photographs (Figure 3).

\section{Systematic Description}

Table 2. Check-list of the fungal remains recovered from the Subathu sediments from Dogadda area, Uttarakhand.

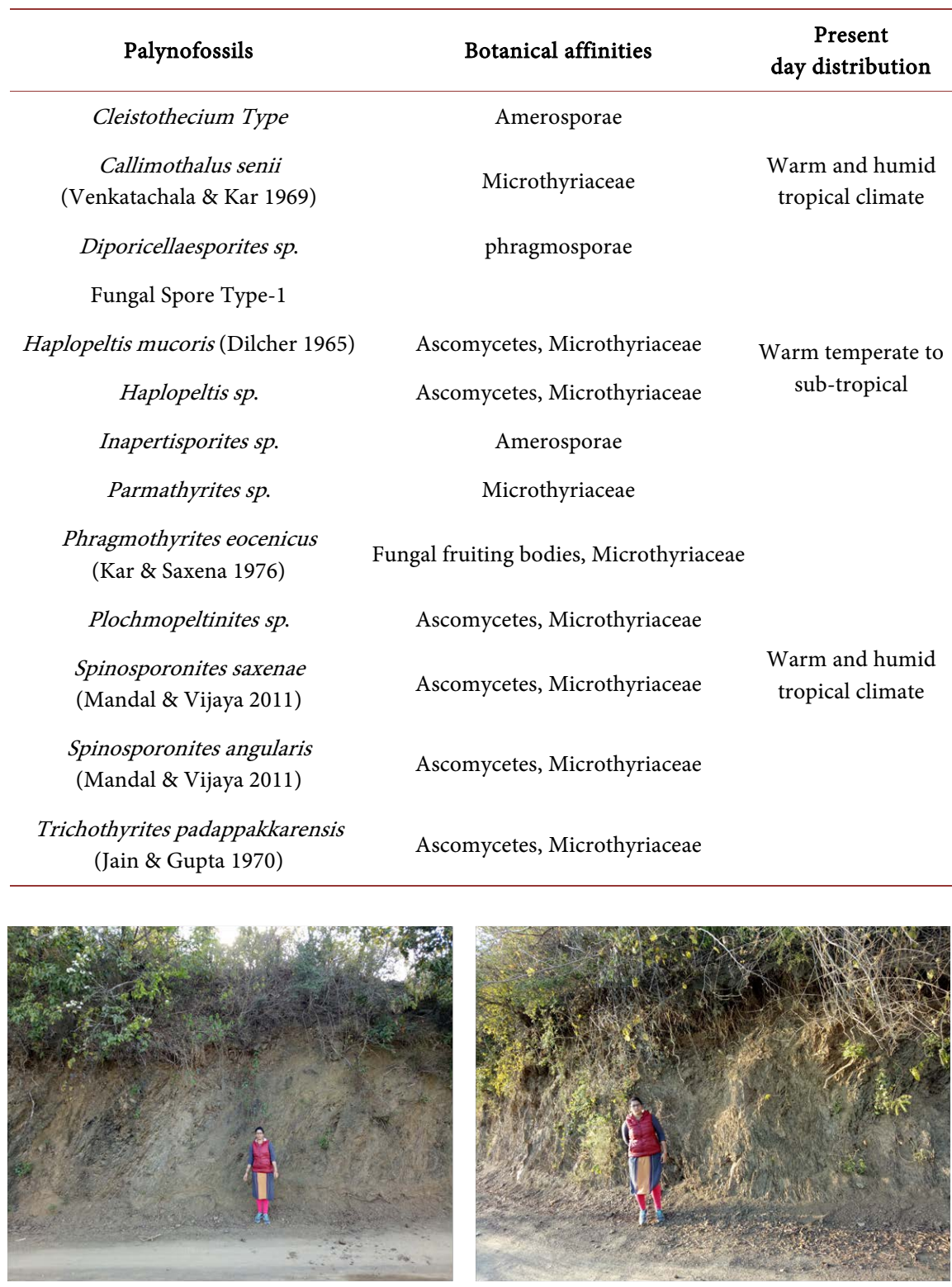

Figure 3. Field photographs showing Subathu lithounit in the Dogadda area, Pauri Garhwal, Uttarakhand. 


\section{Cleistothecium Type}

(Pl. I, Figure 4(k))

Remarks: It is globular and completely closed cleistothecium containing ascocarps. Fruiting body is provided with some hyphae septate appendages, dark in color.

Dimensions: Size $30 \mu \mathrm{m}$, hyphae length $40-60 \mu \mathrm{m}$.

Occurrence: Subathu Formation, Dogadda-Kotdwar section, Dogadda, Uttarakhand.

Affinity: Amerosporae.

Genus: Callimothalus Dilcher, 1965 ex Jansonius \& Hills, 1977.

Type species: Callimothalus pertusus Dilcher, 1965.

Callimothalus senii (Venkatachala \& Kar 1969) Kalgutkar \& Jansonius 2000.

(Pl. I, Figure 4(f))

Remarks: Perithecium subcircular, dark brown in colour, central part of perithecium darker than neighbouring regions, hyphae radially arranged, pseudoparenchymatous, outer layer thickened and minutely setose, Asci not seen.

Dimensions: Size $100-140 \mu \mathrm{m}$.

Occurrence: Subathu Formation, Dogadda-Kotdwar section, Dogadda, Uttarakhand.

Affinity: Ascomycetes, Microthyriaceae.

Genus: Diporicellaesporites Elsik, 1968.

Type species: Diporicellaesporites stacyi Elsik, 1968.

Diporicellaesporites sp.

(Pl. I, Figure 4(m))

Remarks: Spore dark brown in color, 6-celled, fusiformis, central cells comparatively larger in diameter than terminal cells, diporate, one pore at each end, tranverse septa fairly thick, psilateSpore dark.

Dimensions: Size $35 \times 15 \mu \mathrm{m}$.

Occurrence: Subathu Formation, Dogadda-Kotdwar section, Dogadda, Uttarakhand.

Affinity: Phragmosporae

Genus: Haplopeltis

Type species: Haplopeltis

Haplopeltis mucoris Dilcher, 1965

(Pl. I, Figure 4(b))

Remarks: Fungal body is circular to sub-circular in shape, non-radiating, ostiolate present, ostiolate is prominent, central in position, round and surrounded by small cells, no free hyphae present, margins non-radiating and complete.

Dimensions: Diameter $80 \mu \mathrm{m}$, ostiole $10 \mu \mathrm{m}$ in diameter.

Occurrence: Subathu Formation, Dogadda-Kotdwar section, Dogadda, Uttarakhand. 


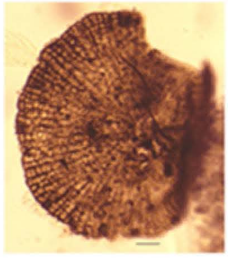

(a)

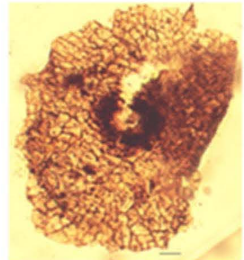

(e)

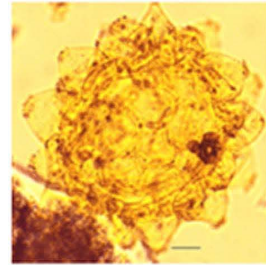

(i)

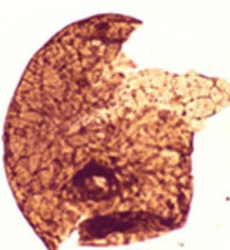

(b)

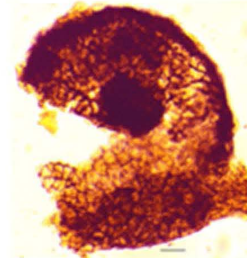

(f)

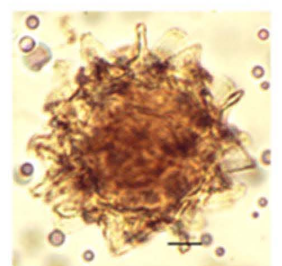

(j)

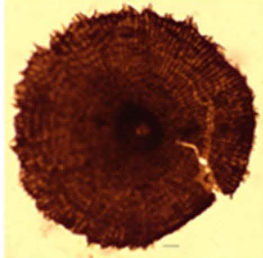

(c)

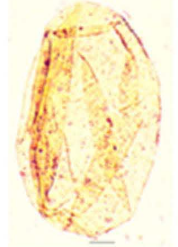

(g)

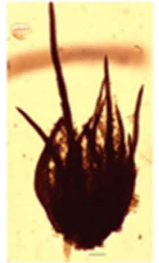

(k)

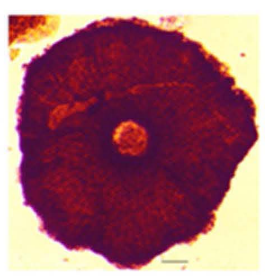

(d)

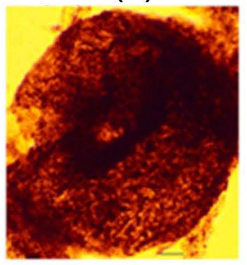

(h)

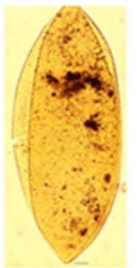

(l)

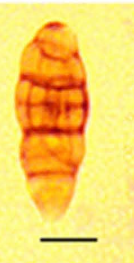

(m)

Figure 4. (a) Phragmothyrites eocaenicus; (b) Haplopeltis mucoris; (c) Parmathyrites sp.; (d) Haplopeltis sp.1; (e) Trichothyrites padappakkarensis; (f) Callimothallus senii; (g) Inapertisporites sp.; (h) Plochmopeltinites sp.; (i) Spinosporonites saxenae; (j) Spinosporonites angularis; (k) Cleistothecium Type; (l) Fungal spore type-I; (m) Dicellaesporites $s p ., 10 \mu \mathrm{m}$.

Affinity: Ascomycetes, Microthyriaceae.

\section{Haplopeltis sp. 1}

(PL. I, Figure 4(d))

Remarks: Fungal body is circular to sub-circular in shape, ostiolate rounds, elevated, dark brown in color, centric, bordered by small cells, fruiting body having non-radiating cells, margin entire, composed of flattened cells.

Dimensions: Diameter $85 \mu \mathrm{m}$, ostiole $10 \mu \mathrm{m}$ in diameter.

Occurrence: Subathu Formation, Dogadda-Kotdwar section, Dogadda, Uttarakhand.

Affinity: Ascomycetes, Microthyriaceae.

Genus: Inapertisporites Van der Hammen, 1954 emend Sheffy \& Dilcher, 1971

Type species: Inapertisporites variabilis van der Hammen, 1954

Inapertisporites $\mathrm{sp}$.

(P1. I, Figure 4(g))

Remarks: Fungal spore having oval shape, unicellate, spore wall thick and laevigate.

Dimensions: Size $90 \times 40 \mu \mathrm{m}$.

Occurrence: Subathu Formation, Dogadda-Kotdwar section, Dogadda, Uttarakhand. 
Affinity: Amerosporae.

Genus: Parmathyrites Jain \& Gupta, 1970.

Type species: Parmathyrites indicus Jain \& Gupta, 1970.

Parmathyrites sp.

(P1. I, Figure 4(c))

Remarks: Ascomata circular in shape, non-ostiolate, hyphae interconnected arranged radially forming pseudoparenchymatous non-porate cells. Central and marginal cells are rectangular in shape, peripheral cells are developed into spine like unequal processes, spines are pointed at apex and broader at the base. Ascospores unknown.

Dimensions: Diameter $80 \mu \mathrm{m}$.

Occurrence: Subathu Formation, Dogadda-Kotdwar section, Dogadda, Uttarakhand.

Affinity: Ascomycetes, Microthyriaceae.

Genus: Phragmothyrites Edwards, 1922 emend. Kar \& Saxena, 1976.

Type species: Phragmothyrites eocaenica Edwards, 1922 emend. Kar \& Saxena, 1976.

Phragmothyrites eocenicus Edwards, 1922 emend. Kar \& Saxena, 1976.

(Pl. I, Figure 4(a))

Remarks: Ascomata circular to sub-circular in shape, non-ostiolate, hyphae radially arranged and interconnected forming one-celled thick pseudoparenchymatous cells. Marginal cells are more elongated then the middle region cells. Marginal cells are more darker, central region bears a single pore.

Dimensions: Diameter $70 \mu \mathrm{m}$.

Occurrence: Subathu Formation, Dogadda-Kotdwar section, Dogadda, Uttarakhand.

Affinity: Ascomycetes, Microthyriaceae.

Genus: Plochmopeltinites Cookson, 1947

Type species: Plochmopeltinites masonii Cookson, 1947

Plochmopeltinites $s p$.

(P1. I, Figure 4(h))

Remarks: Epiphyllous fungi is rounded to rounded irregular in shape, discoid, brown to reddish brown, ostiolate, ostiole centric, dense border with 2 - 3 cell layers.

Dimensions: Size $102 \mu \mathrm{m}$.

Occurrence: Subathu Formation, Dogadda-Kotdwar section, Dogadda, Uttarakhand.

Affinity: Ascomycetes, Microthyriaceae.

Genus: Spinosporonites Saxena \& Khare, 1992

Type species: Spinosporonites indicus Saxena \& Khare, 1992

Spinosporonites saxenae Saxena \& Khare, 1992

(Pl. I, Figure 4(i))

Remarks: Fungal spore is circular to subcircular in shape, inaperturate, multicellate, each cell giving rise to a robustly built rounded spine, wall very 
thin, less than $0-5 \mu \mathrm{m}$, smooth, spines are broader at base.

Dimensions: Size 50 - 60 in diameter, cells are 5 - 7 wide at the base.

Occurrence: Subathu Formation, Dogadda-Kotdwar section, Dogadda, Uttarakhand.

Affinity: Ascomycetes, Microthyriaceae.

Spinosporonites angularis Saxena \& Khare, 1992

(Pl. I, Figure 4(j))

Remarks: Fungal spore is spherical in shape, inaperturate, multicellate, each cell having angular tip and broader base, wall $0-5 \mu \mathrm{m}$ thick and smooth.

Dimensions: Size $44 \times 60$ in diameter.

Occurrence: Subathu Formation, Dogadda-Kotdwar section, Dogadda, Uttarakhand.

Affinity: Ascomycetes, Microthyriaceae.

Genus: Trichothyrites

Type species: Trichothyrites

\section{Trichothyrites padappakkarensis}

(P1. I, Figure 4(e))

Remarks: Ascostromata is circular-subcircular in shape, ostiolate, ostiole surrounded by wall of few cells, hyphae radially arranged but donot anastomose to form distinct pseudoparenchymatous cells.

Dimensions: Diameter $70 \mu \mathrm{m}$.

Occurrence: Subathu Formation, Dogadda-Kotdwar section, Dogadda, Uttarakhand.

Affinity: Ascomycetes, Microthyriaceae.

\section{Discussions}

Dominant retrieval of multiple forms of epiphyllous fungi i.e., Callimothalus senii, Haplopeltis mucoris, Haplopeltis sp., Parmathyrites sp., Phragmothyrites eocaenicus, Plochmopeltinites sp., Spinosporonites saxenae, Spinosporonites angularis and Trichothyrites padappakkarensis in majority provides authentic evidence for the prevalence of high humidity coupled with high temperature for the luxuriant growth of this group of plants. Although, modern microthyriaceous fungi infect both coniferous as well as angiospermous leaves. Also, the fossil taxa related to these fungi have been discovered on coniferous as well as angiospermous leaves [12] [13] [14] [15]. But, no coniferous remains have been recorded from the Subathus of Dogadda while angiospermic remains in the form of pollen grains are known abundantly from this lithounit. This obviously indicates that the microthyriaceous fungi recorded from the studied area are entirely depended on the angiosperm foliage only.

During Tertiary period, the distribution of microthyriaceous fungi shows globally appearance as evidenced by their occurrence in Scotland, Sicily, Sumatra, Siberia, Germany, Australia, USA, Western Canada, South Africa and India. At present, these fungal found in abundance in humid tropical to sub-tropical areas 
of the world with high rainfall. While, some of the members like Plochmopeltinies have enjoyed wider distribution during the tertiary period in comparison to present day distribution [13]. The occurrence of microthyriaceous fungi and their germlings in the deposits is a good indicator of moist tropical type of vegetation [16]. Microthyriaceous taxa are usually coorelated with humid, warm temperate to tropical climate [16]-[20]. The presence of microthyriaceous taxa supports swampy habitat during the deposition. Occurrence of Inapertisporites $s p$. and Dicellaesporites $s p$. indicates humid, tropical type of climate. The plate showing representative photographs of assemblage recovered is shown in (Figure 4). Based on the occurence of the Callimothalus senii (Late Paleocene - Miocene), Haplopeltis mucoris (Early Eocene), Phragmothyrites eocenicus (Late Paleocene - Middle Miocene), Spinosporonites saxenae (Late Paleocene - Middle Miocene), Spinosporonites angularis (Late Paleocene - Middle Miocene) in the present fungal assemblage, Late Palaeocene-Middle Eocene age is assigned to this horizon of Dogadda-Kotdwar section, Dogadda area, Pauri-Garhwal district, Uttarakhand.

\section{Conclusions}

1) The present paper records assemblage constituting 13 species assignable to 10 form genera of fungal remains from the Subathu Formation of Dogadda area, Uttarakhand.

2) The assemblage suggests that the region experienced warm and humid climate during the course of sediment accumulation with thick vegetation providing suitable substrates for the growth and proliferation of fungi.

3) The assemblage indicates moist tropical type of vegetation based on the dominance of microthyriaceous fungal assemblage.

4) The present fungal assemblage depends on the broad leaf angiosperm foliage.

5) The present horizon reported Late Palaeocene-Middle Eocene age diagnostic palynotaxa (Callimothalus senii, Haplopeltis mucoris, Phragmothyrites eocenicus, Spinosporonites saxenae, Spinosporonites angularis), Late Palaeocene-Middle Eocene age is assigned to the present horizon.

\section{Acknowledgements}

Authors are grateful to the Chairman, Department of Geology, Kurukshetra University, Kurukshetra for providing necessary lab facilities for accomplishment of the research work.

\section{Conflicts of Interest}

The authors declare no conflicts of interest regarding the publication of this paper.

\section{References}

[1] Oldham, R.D. (1884) Note on the Geology of Part of the Gangasulan Pargana of 
British Garhwal. Records of the Geological Survey of India, 17, 161-167.

[2] Middlemiss, C.S. (1887) Physical Geology of West British Garhwal with a Note on a Route Traverse through Jaunsar, Barwar and Tiri Garhwal. Records of the Geological Survey of India, 20, 26-40.

[3] Prakash, R. and Swarup, P. (1961) Administrative Report. Directorate of Geology and Mining, Uttar Pradesh.

[4] Mathur, N.S. (1977) Age of the Tal and Subathu Formation in the Garhwal Region, Uttar Pradesh, India. Bulletin of the Indian Geologists Association, 10, 21-27.

[5] Mathur, N.S. (1978) Biostratigraphical Aspects of the Subathu Formation, Kumaun Himalaya. Recent Researches in Geology, 5, 96-112.

[6] Mathur, N.S. and Juyal, K.P. (2000) Atlas of Early Paleogene Invertebrate Fossils of the Himalayan Foothills Belt. Wadia Institute of Himalayan Geology, Monograph Series No. 1, 1-257.

[7] Singh, P. (1980) Note on the Geology of the Subathu Group of the Nilkanth, Garhwal Himalaya. Geoscience Journal, 1, 81-83.

[8] Srikantia, S.V. and Bhargava, O.N. (1998) Geology of Himachal Pradesh. Geological Society of India, Bangalore, 1-408.

[9] Tewari, B.S. and Singh, J. (1976) Microfossils and the Age of the Subathu Formation of Dogadda, Garhwal Himalaya. Journal of the Geological Society of India, 17, 409-411.

[10] Srivastava, D.K., Dhaundiyal, J.N. and Kumar, G. (1979) Lamellibranch Fauna from the Eocene Rocks of the Garhwal Synform, U.P, India. Ninth. Sem. Hima. Geol., abs no. 22 .

[11] Shanker, R. and Ganeshan, T.M. (1973) A Note on Garhwal Nappe. Himalayan Geology, 3, 72-82.

[12] Edwards, W.N. (1922) An Eocene Microthyriaceous Fungus from Mull, Scotland. Transactions of the British Mycological Society, 8, 66-72.

https://doi.org/10.1016/S0007-1536(22)80008-5

[13] Cookson, I.C. (1947) Fossil Fungi from Tertiary Deposits in the Southern Hemisphere, Part I. Proceedings of the Linnean Society of New South Wales, 72, 207-214.

[14] Popov, P.A. (1960) Remains of Tertiary Fungi Microthyriaceae Sacc in the Yenisey Region of the West-Siberian Lowland. Doklady Akademii Nauk SSSR, 131, 1152-1155. (In Russian)

[15] Dilcher, D.L. (1965) Epiphyllous Fungi from Eocene Deposits in Western Tennessee, USA. Palaeontographica B, 116, 1-54.

[16] Lange, R.T. (1976) Fossil Epiphyllous "Germlings" Their Living Equivalents and Their Paleohabitat Indicator Value. Neues Jahrbuch für Geologie und Paläontologie-Abhandlungen, 151, 142-165.

[17] Elsik, W.C. (1978) Classification \& Geologic History of the Microthyriaceous Fungi. Proceedings of the IV International Palynological Conference, Lucknow, Vol. 1, 331-342.

[18] Kalgutkar, R.M. and Jansonius, J. (2000) Synopsis of Fossil Fungal Spores, Mycelia \& Fructifications. American Association of Stratigraphic Palynologist Foundation Contributions Series No. 39, I-429.

[19] Tripathi, S.K.M. (2009) Fungi from Palaeoenvironents: Their Role in Environmental Interpretations. In: Misra, J.K. and Deshmukh, S.K., Eds., Fungi from Different Environments, Progress in Mycological Research Series, Science Publishers, Enfield, $1-27$. 
[20] Conran, J.G., Bannister, J.M., Reichgelt, T. and Lee, D.E. (2016) Epiphyllous Fungi \& Leaf Physiognomy Suggest an Ever-Wet Humid Mesothermal (Subtropical) Climate in the Late Eocene of Southern New Zealand. Palaeogeography, Palaeoclimatology, Palaeoecology, 452, 1-10. https://doi.org/10.1016/j.palaeo.2016.03.032 